\title{
BMJ Open Efficacy and safety of nesiritide in patients with decompensated heart failure: a meta-analysis of randomised trials
}

\author{
Bojun Gong, ${ }^{1}$ Zhineng Wu, ${ }^{2}$ Zicheng $\mathrm{Li}^{1}$
}

To cite: Gong B, Wu Z, Li Z. Efficacy and safety of nesiritide in patients with decompensated heart failure: a meta-analysis of randomised trials. BMJ Open 2016;6: 008545 .

doi:10.1136/bmjopen-2015008545

- Prepublication history for this paper is available online. To view these files please visit the journal online (http://dx.doi.org/10.1136/ bmjopen-2015-008545).

Received 21 April 2015 Revised 25 November 2015 Accepted 15 December 2015

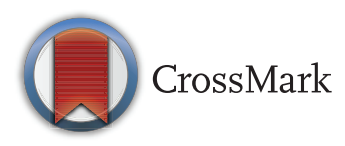

${ }^{1}$ Department of Cardiology, First Affiliated Hospital of Jinan University, Guangzhou, PR China

${ }^{2}$ University of South China, Hunan, PR China

Correspondence to

Bojun Gong;

bojungong@hotmail.com

\section{ABSTRACT}

Objectives: Current evidence suggests that nesiritide may have effects on renal function and decrease the incidence of mortality. However, a clear superiority using nesiritide in terms of renal toxicity and mortality in patients with heart failure was not consistently proven by previous studies. We performed a metaanalysis of all randomised trials to obtain the best estimates of efficacy and safety of nesiritide for the initial treatment of decompensated heart failure.

Method: We performed a meta-analysis of randomised trials of nesiritide in patients with decompensated heart failure $(n=38064$ patients, in 22 trials). Two reviewers independently extracted data. Data on efficacy and safety outcomes were collected. We calculated pooled relatives risk (RRs), weighted mean difference and associated 95\% Cls.

Results: Compared with placebo, dobutamine and nitroglycerin, nesiritide indicated no increasing risk of total mortality. Compared with the combined control therapy, nesiritide was associated with non-significant differences in short-term mortality (RR $1.24 ; 95 \% \mathrm{Cl}$ 0.85 to $1.80 ; p=0.27$ ), mid-term mortality (RR 0.86 ; $95 \% \mathrm{Cl} 0.60$ to $1.24 ; \mathrm{p}=0.42$ ) and long-term mortality (RR $0.94 ; 95 \% \mathrm{Cl} 0.75$ to $1.18 ; p=0.61$ ). Nesiritide therapy increased the risk of hypotension $(p<0.00001)$ and bradycardia $(p=0.02)$ when compared with control therapy. Compared with dobutamine or placebo therapy, no differences in serum creatinine, blood urea nitrogen and creatinine clearance, and no risk of the need for dialysis was observed in nesiritide therapy. Conclusions: Our findings indicated that, in patients with heart failure, nesiritide was not associated with the risk of mortality. However, it increased the risk of cardiovascular adverse events. The change of serum creatinine and creatinine clearance had no significant difference, and no risk of the need for dialysis was observed after low-dose nesiritide treatment.

\section{INTRODUCTION}

Advanced decompensated chronic heart failure (CHF) is one of the most frequent reasons for hospital admissions in patients

\section{Strengths and limitations of this study}

- In this meta-analysis, we evaluated the efficacy and safety of nesiritide in patients with decompensated heart failure. We demonstrated that nesiritide was not associated with total mortality, short-term mortality, mid-term mortality and long-term mortality. However, it increased the risk of cardiovascular adverse events.

- Several limitations of the present meta-analysis should be considered. First, the primary limitation is lack of complete mortality data. Not all the studies in this report described total mortality and long-term mortality. Second, all the studies lasted for $<12$ weeks and no study lasted more than a year which limited our assessment of long-term mortality. Finally, this analysis has not reached out to all racial and ethnic groups, and we only include English language studies.

over the age of 65 years, ${ }^{1}$ with more than one million people in the USA hospitalised each year. ${ }^{2}$ Decompensated heart failure is a complex syndrome mainly caused by left or right ventricular dysfunction rather than being a single problem of low cardiac output. It is associated with endothelial dysfunction, which contributes to the pathophysiology of the syndrome, ${ }^{3}{ }^{4}$ and is also connected with increased local and systemic release of oxygen-derived free radicals that cause myocardial dysfunction in patients with this syndrome. ${ }^{5}$ Inflammatory and neurohormonal activation play a significant role in the pathophysiology of decompensated heart failure. ${ }^{6}$ Despite optimal diuretics, vasodilators and oral therapy, patients with evidence of peripheral hypoperfusion and clinical deterioration also may receive positive inotropic agents, usually milrinone or dobutamine.

Nesiritide, a vasodilator agent and recombinant human brain or B-type natriuretic peptide $^{7-9}$ for the treatment of acutely 
Table 1 Characteristics of the 22 studies included in the meta-analysis

\begin{tabular}{|c|c|c|c|c|c|c|c|c|c|c|c|c|c|}
\hline Study & Year & $\begin{array}{l}\text { Country } \\
\text { and } \\
\text { centres }\end{array}$ & Blinding & $\begin{array}{l}\text { Sample } \\
\text { size }\end{array}$ & Population & $\begin{array}{l}\text { Intervention } \\
\text { drug }\end{array}$ & $\begin{array}{l}\text { Nesiritide } \\
\text { bolus, } \mu \mathrm{g} / \\
\text { kg }\end{array}$ & $\begin{array}{l}\text { Nesiritide } \\
\text { infusion, } \\
\mu \mathrm{g} / \mathrm{kg} / \mathrm{min}\end{array}$ & $\begin{array}{l}\text { Nesiritide } \\
\text { duration, } \\
\text { h }\end{array}$ & $\begin{array}{l}\text { Control } \\
\text { drug }\end{array}$ & $\begin{array}{l}\text { Follow-up, } \\
\text { months }\end{array}$ & $\begin{array}{l}\text { Lost to } \\
\text { follow-up, } \\
\text { days }\end{array}$ & $\begin{array}{l}\text { Jadad } \\
\text { score }\end{array}$ \\
\hline Abraham et $a 1^{19}$ & 2005 & Multicentres & $\begin{array}{l}\text { Double } \\
\text { blind }\end{array}$ & 489 & $\begin{array}{l}\text { Acutely } \\
\text { decompensated } \\
\text { congestive heart } \\
\text { failure }\end{array}$ & Nesiritide & 2 & 0.01 & 24 & $\begin{array}{l}\text { Nitroglycerin } \\
\text { and placebo }\end{array}$ & Hosp & 0 & 5 \\
\hline Burger et $a^{20}$ & 2001 & Multicentres & Open & 261 & $\begin{array}{l}\text { Acutely } \\
\text { decompensated } \\
\text { congestive heart } \\
\text { failure }\end{array}$ & Nesiritide & 0.3 & $\begin{array}{l}0.015 \text { and } \\
0.03\end{array}$ & UNK & Dobutamine & 21 days & 0 & 3 \\
\hline Burger et $a l^{12}$ & 2002 & Multicentres & Open & 255 & $\begin{array}{l}\text { Decompensated } \\
\text { congestive heart } \\
\text { failure }\end{array}$ & Nesiritide & 0 & $\begin{array}{l}0.015 \text { and } \\
0.03\end{array}$ & 24 & Dobutamine & 14 days & 0 & 3 \\
\hline $\begin{array}{l}\text { O'Connor } \\
\text { et } a l^{16}\end{array}$ & 2011 & Multicentres & $\begin{array}{l}\text { Double } \\
\text { blind }\end{array}$ & 7141 & $\begin{array}{l}\text { Acute heart } \\
\text { failure }\end{array}$ & Nesiritide & 2 & 0.01 & 24 & Placebo & 30 days & 0 & 5 \\
\hline Arora et $a^{21}$ & 2007 & $\begin{array}{l}\text { USA, single } \\
\text { centre }\end{array}$ & UNK & 206 & $\begin{array}{l}\text { Acute } \\
\text { decompensated } \\
\text { heart failure }\end{array}$ & Nesiritide & 2 & 0.01 & 24 & Placebo & Hosp & 0 & 3 \\
\hline Silver et $a f^{22}$ & 2002 & Multicentres & $\begin{array}{l}\text { Double } \\
\text { blind }\end{array}$ & 261 & $\begin{array}{l}\text { Decompensated } \\
\text { heart failure }\end{array}$ & Nesiritide & $\begin{array}{l}0.3 \text { and } \\
0.6\end{array}$ & $\begin{array}{l}0.015 \text { and } \\
0.03\end{array}$ & 24 & Dobutamine & 6 & 2 & 4 \\
\hline Witteles et $a^{P^{3}}$ & 2007 & Multicentres & $\begin{array}{l}\text { Double } \\
\text { blind }\end{array}$ & 75 & $\begin{array}{l}\text { Acute } \\
\text { decompensated } \\
\text { heart failure }\end{array}$ & Nesiritide & 2 & 0.01 & 48 & Placebo & 30 days & 0 & 5 \\
\hline $\begin{array}{l}\text { Aronson and } \\
\text { Burger }^{24}\end{array}$ & 2002 & Multicentres & UNK & 82 & $\begin{array}{l}\text { Decompensated } \\
\text { congestive heart } \\
\text { failure }\end{array}$ & Nesiritide & UNK & $\begin{array}{l}0.015 \text { and } \\
0.03\end{array}$ & 24 & Dobutamine & Hosp & 0 & 4 \\
\hline $\begin{array}{l}\text { The VMAC } \\
\text { study }{ }^{11}\end{array}$ & 2002 & Multicentres & $\begin{array}{l}\text { Double } \\
\text { blind }\end{array}$ & 489 & $\begin{array}{l}\text { Decompensated } \\
\text { congestive heart } \\
\text { failure }\end{array}$ & Nesiritide & 1 & 0.01 & 24 & $\begin{array}{l}\text { Nitroglycerin } \\
\text { and placebo }\end{array}$ & 6 & 0 & 5 \\
\hline Colucci et $a^{\beta}$ & 2000 & Multicentres & Open & 432 & $\begin{array}{l}\text { Symptomatic } \\
\text { congestive heart } \\
\text { failure }\end{array}$ & Nesiritide & $\begin{array}{l}0.3 \text { and } \\
0.6\end{array}$ & $\begin{array}{l}0.015 \text { and } \\
0.03\end{array}$ & 3 & Placebo & 21 days & 0 & 4 \\
\hline Chen et $a^{25}$ & 2013 & Multicentres & $\begin{array}{l}\text { Double } \\
\text { blind }\end{array}$ & 360 & $\begin{array}{l}\text { Acute heart } \\
\text { failure and renal } \\
\text { dysfunction }\end{array}$ & Nesiritide & 0 & 0.005 & 24 & $\begin{array}{l}\text { Dobutamine } \\
\text { and placebo }\end{array}$ & 180 days & 4 & 5 \\
\hline Chow et $a$ f $^{26}$ & 2011 & $\begin{array}{l}\text { USA, single } \\
\text { centre }\end{array}$ & Open & 89 & $\begin{array}{l}\text { Acutely } \\
\text { decompensated } \\
\text { heart failure }\end{array}$ & Nesiritide & 2 & 0.01 & 24 & Nitroglycerin & Hosp & UNK & 3 \\
\hline Peacock et $a{ }^{7}$ & 2005 & Multicentres & $\begin{array}{l}\text { Double } \\
\text { blind }\end{array}$ & 237 & $\begin{array}{l}\text { Acutely } \\
\text { decompensated } \\
\text { heart failure }\end{array}$ & Nesiritide & 2 & 0.01 & 12 & Placebo & Hosp & UNK & 4 \\
\hline Peacock et $a{ }^{8}$ & 2004 & Multicentres & & 61 & & Nesiritide & 2 & 0.01 & 24 & Nitroglycerin & 6 & 0 & 5 \\
\hline
\end{tabular}

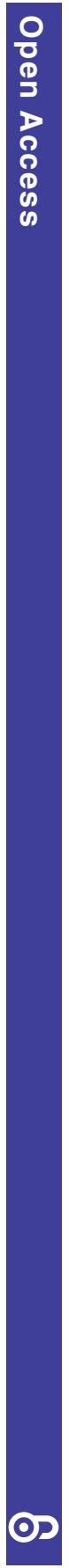




\begin{tabular}{|c|c|c|c|c|c|c|c|c|c|c|c|c|c|}
\hline Study & Year & $\begin{array}{l}\text { Country } \\
\text { and } \\
\text { centres }\end{array}$ & Blinding & $\begin{array}{l}\text { Sample } \\
\text { size }\end{array}$ & Population & $\begin{array}{l}\text { Intervention } \\
\text { drug }\end{array}$ & $\begin{array}{l}\text { Nesiritide } \\
\text { bolus, } \mu g / \\
\text { kg }\end{array}$ & $\begin{array}{l}\text { Nesiritide } \\
\text { infusion, } \\
\mu \mathrm{g} / \mathrm{kg} / \mathrm{min}\end{array}$ & $\begin{array}{l}\text { Nesiritide } \\
\text { duration, } \\
\text { h }\end{array}$ & $\begin{array}{l}\text { Control } \\
\text { drug }\end{array}$ & $\begin{array}{l}\text { Follow-up, } \\
\text { months }\end{array}$ & $\begin{array}{l}\text { Lost to } \\
\text { follow-up, } \\
\text { days }\end{array}$ & $\begin{array}{l}\text { Jadad } \\
\text { score }\end{array}$ \\
\hline & & & $\begin{array}{l}\text { Double } \\
\text { blind }\end{array}$ & & $\begin{array}{l}\text { Patients with } \\
\text { dyspnoea at rest } \\
\text { resulting from } \\
\text { heart failure }\end{array}$ & & & & & & & & \\
\hline Peacock et $a{ }^{29}$ & 2005 & Multicentres & $\begin{array}{l}\text { Double } \\
\text { blind }\end{array}$ & 250 & $\begin{array}{l}\text { Acutely } \\
\text { decompensated } \\
\text { heart failure }\end{array}$ & Nesiritide & 2 & 0.01 & 12 & Placebo & 30 days & 1 & 5 \\
\hline Styron et $a^{\beta 0}$ & 2009 & Multicentres & UNK & 595 & Heart failure & Nesiritide & UNK & NA & UNK & Placebo & 180days & 0 & 3 \\
\hline Carroll et $a{ }^{\beta 1}$ & 2007 & Multicenters & Open & 25330 & $\begin{array}{l}\text { Congestive heart } \\
\text { failure }\end{array}$ & Nesiritide & UNK & NA & UNK & Placebo & Hosp & 0 & 3 \\
\hline $\begin{array}{l}\text { Yancy and } \\
\text { Singh }^{32}\end{array}$ & 2006 & Multicentres & Open & 138 & $\begin{array}{l}\text { Advanced heart } \\
\text { failure and renal } \\
\text { insufficiency }\end{array}$ & Nesiritide & 1 and 2 & $\begin{array}{l}0.005 \text { and } \\
0.01\end{array}$ & 14 days & Placebo & 3 & 4 & 3 \\
\hline Chow et $a^{\beta 3}$ & 2011 & $\begin{array}{l}\text { USA, single } \\
\text { centre }\end{array}$ & UNK & 89 & $\begin{array}{l}\text { Cardiorenal } \\
\text { syndrome with } \\
\text { acute } \\
\text { decompensated } \\
\text { heart failure }\end{array}$ & Nesiritide & 2 & 0.01 & 48 & Nitroglycerin & 6 & 0 & 3 \\
\hline Yancy et $a{ }^{\beta 4}$ & 2004 & Multicentres & Open & 210 & $\begin{array}{l}\text { Decompensated } \\
\text { heart failure }\end{array}$ & Nesiritide & 1 and 2 & $\begin{array}{l}0.005 \text { and } \\
0.01\end{array}$ & 6 & Placebo & 3 & 0 & 3 \\
\hline Yancy et $a l^{35}$ & 2008 & Multicentres & $\begin{array}{l}\text { Double } \\
\text { blind }\end{array}$ & 911 & $\begin{array}{l}\text { Acutely } \\
\text { decompensated } \\
\text { heart failure }\end{array}$ & Nesiritide & 2 & 0.01 & 6 & Placebo & 3 & 5 & 5 \\
\hline Mills et $a^{\beta 6}$ & 1999 & Multicentres & $\begin{array}{l}\text { Double } \\
\text { blind }\end{array}$ & 103 & $\begin{array}{l}\text { Decompensated } \\
\text { heart failure }\end{array}$ & Nesiritide & $\begin{array}{l}0.25,0.5 \\
\text { and } 1.0\end{array}$ & $\begin{array}{l}0.015 \text { and } \\
0.03\end{array}$ & 24 & Placebo & Hosp & UNK & 5 \\
\hline
\end{tabular}




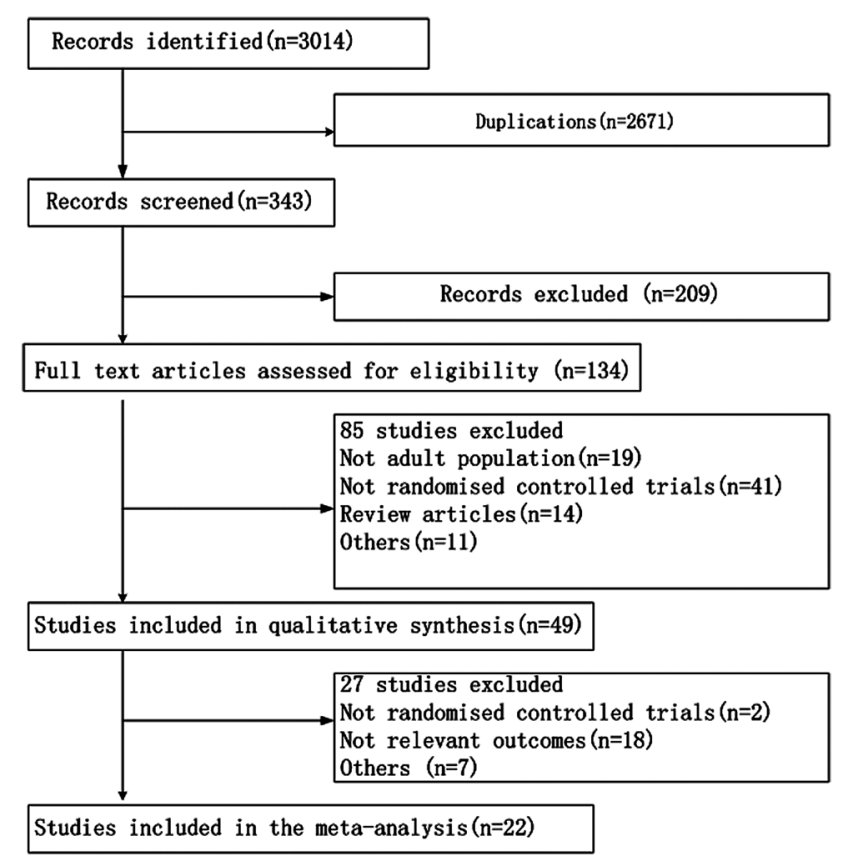

Figure 1 PRISMA flow diagram.

decompensated heart failure produced primarily by the ventricular myocardium in response to volume and pressure overload, ${ }^{10}$ was approved by the Food and Drug Administration in 2001, and became the first new therapy for acute decompensated heart failure in 14 years.

In clinical studies, nesiritide had been found to acutely reduce pulmonary capillary wedge pressure (PCWP), systemic blood pressure, left ventricular filling pressure and systemic vascular resistance (SVR) ${ }^{8}{ }^{11-13}$ It also increased cardiac output without direct inotropic effects, promoted diuresis by opposing the effects of endothelin 1, and improved short-term symptoms of dyspnoea and glomerular filtration rate. ${ }^{8}{ }^{11}$ However, two recently published meta-analyses ${ }^{14}{ }^{15}$ and one large randomised trial ${ }^{16}$ prompted further debate about the role of nesiritide for the initial treatment of heart failure. Two meta-analyses illustrated that worsening renal function and higher short-term mortality were associated with nesiritide, ${ }^{14} 15$ whereas one large randomised trial by O'Connor et $a l^{16}$ showed that nesiritide was not associated with a worsening of renal function and the risk of mortality.

When properly applied, meta-analysis can increase the statistical power of primary endpoints, clarity disagreement among studies, and estimate effect sizes to quantify outcomes from a set of individual studies. ${ }^{17}$ To further clarify the role of nesiritide, we performed an updated meta-analysis of randomised trials comparing nesiritide with placebo, dobutamine, or nitroglycerin, for the initial treatment of decompensated heart failure, with particular references to the efficacy and safety.

\section{METHODS}

We attempted to identify all relevant published randomised studies comparing nesiritide with dobutamine, nitroglycerin, or placebo, for the initial treatment of decompensated heart failure. We searched between October 1950 and October 2015 from MEDLINE, between January 1980 and October 2015 from EMBASE, and between January 1976 and October 2015 from the Cochrane Library for English-language randomised controlled trials, using the terms "heart failure", "nesiritide", "dobutamine", "placebo", "nitroglycerin", "controlled clinical trial", "randomized controlled trial" and "random". We also performed a manual search of references from original articles and pertinent reviews.

\section{Study selection}

The articles were independently assessed by two investigators (BG and $\mathrm{ZW})$. Disagreements were resolved by consensus with a third reviewer.

Criteria for inclusions were: (1) randomised, (2) conducted in patients with heart failure, (3) compared nesiritide with dobutamine, nitroglycerin, or placebo for the initial treatment of heart failure, (4) low doses of nesiritide $(\leq 0.015 \mu \mathrm{g} / \mathrm{kg} / \mathrm{min})$ and high doses of nesiritide $(>0.015 \mu \mathrm{g} / \mathrm{kg} / \mathrm{min})$ and (5) use of objective methods to assess one or more clinical outcomes, including the efficacy and safety outcomes.

\section{Outcomes}

Study outcomes were analysed comparing the results from 22 trials with nesiritide versus dobutamine, placebo, or nitroglycerin.
Figure 2 Methodological quality of included studies according to the Cochrane Collaboration's tool for assessing risk of bias.

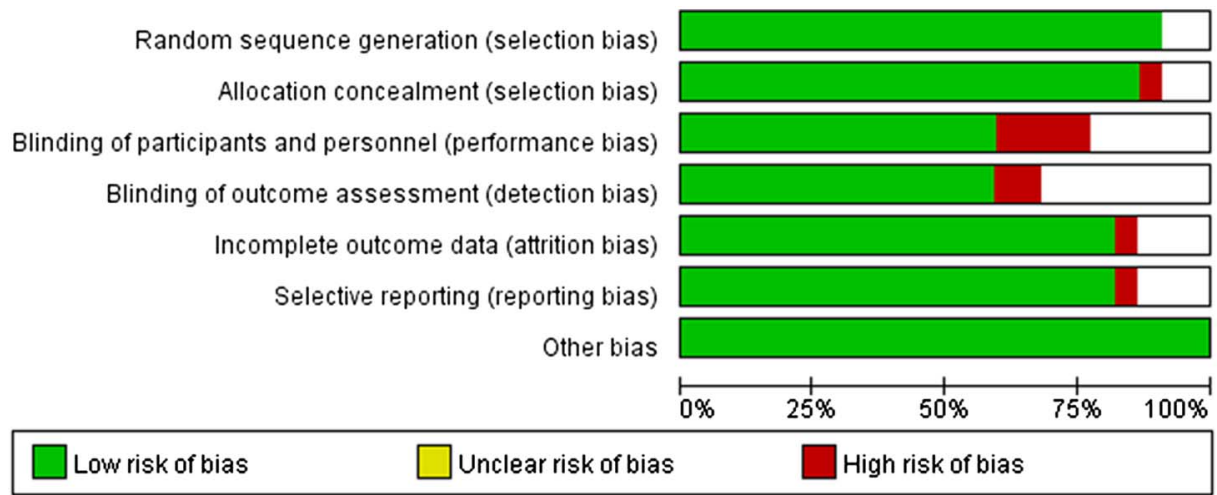


Table 2 Measures of clinical outcomes after the therapeutic intervention

\begin{tabular}{|c|c|c|c|c|c|}
\hline Control group & Outcome & Studies, n & WMD & $95 \% \mathrm{Cl}$ & p Value \\
\hline \multicolumn{6}{|c|}{ High-dose nesiritide } \\
\hline \multirow[t]{2}{*}{ Placebo } & SVR (dynes/s/cm ${ }^{-5}$ ) & 2 & -305.17 & -493.96 to -116.38 & 0.002 \\
\hline & $\mathrm{SBP}(\mathrm{mm} \mathrm{Hg})$ & 2 & -6.87 & -11.01 to -2.73 & 0.001 \\
\hline \multirow[t]{2}{*}{ Dobutamine } & $\mathrm{DBP}(\mathrm{mm} \mathrm{Hg})$ & 1 & -6.3 & -12.39 to -0.21 & 0.04 \\
\hline & $\mathrm{SBP}(\mathrm{mm} \mathrm{Hg})$ & 1 & -6.3 & -12.39 to -0.21 & 0.04 \\
\hline \multicolumn{6}{|c|}{ Low-dose nesiritide } \\
\hline \multirow[t]{5}{*}{ Placebo } & PCWP $(\mathrm{mm} \mathrm{Hg})$ & 3 & -4.35 & -4.35 to -3.33 & $<0.00001$ \\
\hline & SVR (dynes $/ \mathrm{s} / \mathrm{cm}^{-5}$ ) & 3 & -95.35 & -178.09 to -12.06 & 0.02 \\
\hline & $\mathrm{RAP}(\mathrm{mm} \mathrm{Hg})$ & 3 & -5.6 & -8.99 to -2.21 & 0.001 \\
\hline & $\mathrm{SCr}(\mathrm{mg} / \mathrm{dL})$ & 1 & -0.02 & -0.11 to 0.07 & 0.66 \\
\hline & BUN (mg/dL) & 1 & -2.9 & -8.85 to 3.05 & 0.34 \\
\hline Dobutamine & $\mathrm{DBP}(\mathrm{mm} \mathrm{Hg})$ & 2 & -2.21 & -3.43 to -0.98 & 0.0004 \\
\hline \multirow[t]{5}{*}{ Nitroglycerin } & PCWP (mm Hg) & 2 & -2.21 & -3.43 to -0.98 & 0.0004 \\
\hline & $\mathrm{RAP}(\mathrm{mm} \mathrm{Hg})$ & 1 & -2.2 & -3.45 to -0.95 & 0.0005 \\
\hline & $\mathrm{SBP}(\mathrm{mm} \mathrm{Hg})$ & 1 & -3.9 & -6.92 to -0.88 & 0.01 \\
\hline & $\mathrm{SCr}(\mathrm{mg} / \mathrm{dL})$ & 2 & -0.04 & -0.17 to 0.08 & 0.49 \\
\hline & $\mathrm{CrCl}(\mathrm{mL} / \mathrm{min})$ & 2 & -0.82 & -6.95 to 5.31 & 0.79 \\
\hline
\end{tabular}

BUN, blood urea nitrogen; $\mathrm{CrCl}$, creatinine clearance; DBP, diastolic blood pressure; PCWP, pulmonary capillary wedge pressure; RAP, right atrial pressure; SBP, systolic blood pressure; SCr, serum creatinine; SVR, systemic vascular resistance; WMD, weighted mean difference.

The efficacy outcomes were PCWP, right atrial pressure (RAP), SVR, systolic blood pressure (SBP), diastolic blood pressure (DBP), serum creatinine (SCr), blood urea nitrogen $(\mathrm{BUN})$ and creatinine clearance $(\mathrm{CrCl})$.

The safety outcomes were mortality, noncardiovascular adverse events and cardiovascular adverse events. According to its follow-up duration, mortality was divided into three parts: early term ( $\leq 30$ days), midterm ( $>30$ days to 6 months), and long term ( $>6$ months). Non-cardiovascular adverse events were nausea, headache, abdominal pain and the need for dialysis. Cardiovascular adverse events were hypotension (asymptomatic and symptomatic), ventricular extrasystole, ventricular tachycardia (sustained and non-sustained), cardiac arrest, bradycardia and angina pectoris.

\section{Statistical analyses}

We determined pooled relative risks (RRs), weighted mean difference (WMD) and corresponding 95\% CIs, for mortality, non-cardiovascular adverse events, cardiovascular adverse events, haemodynamic parameters and renal function parameters, in patients with heart failure who received nesiritide or treatment with dobutamine, nitroglycerin, or placebo. Furthermore, heterogeneity was assessed using the $\chi^{2}$ test and the $\mathrm{I}^{2}$ measure of inconsistency. If no heterogeneity was found, meta-analysis was performed using a fixed effects model (Mantel-Haenszel method). ${ }^{18}$ Results obtained with a fixed effects model were also compared with those obtained with a random-effects model. All analyses were performed using Review Manager (V.5.1).

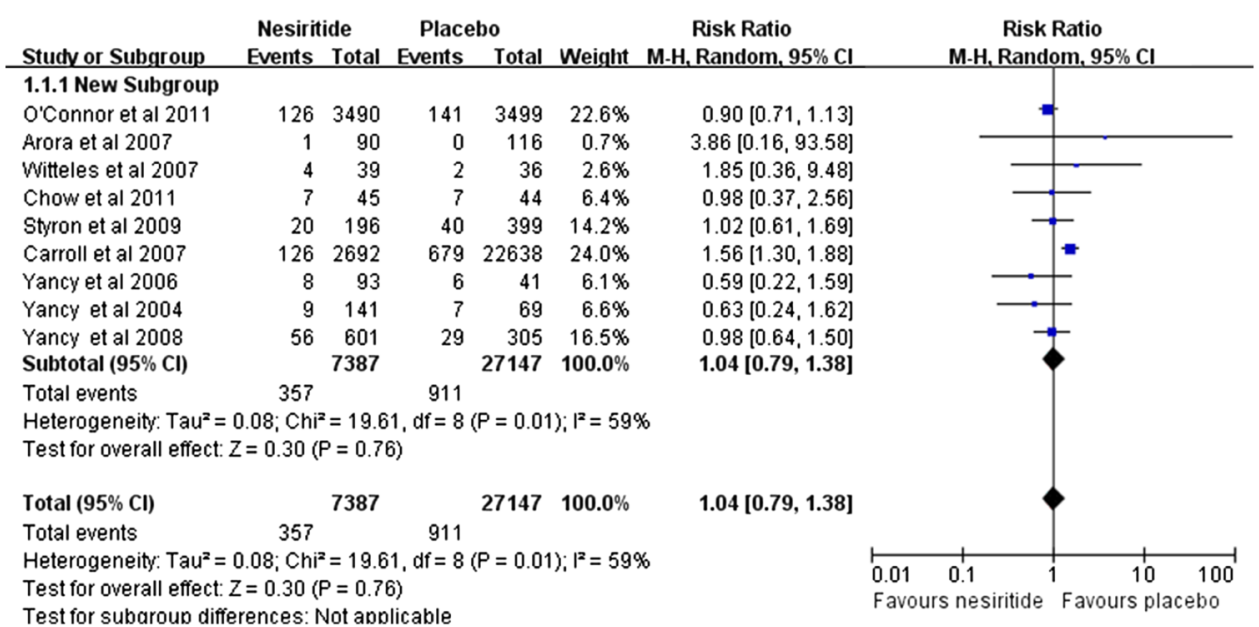

Figure 3 Meta-analysis for the comparison of total mortality in nesiritide versus placebo group (RR, risk ratio). 


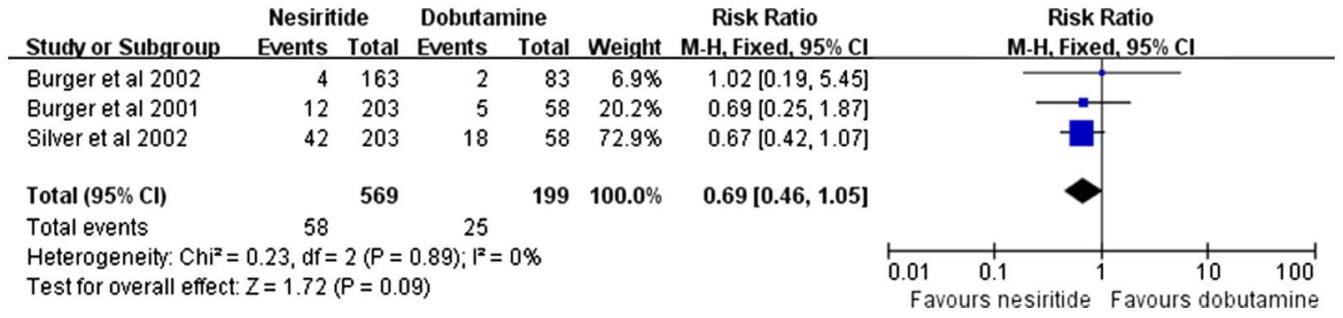

Figure 4 Meta-analysis for the comparison of total mortality in nesiritide versus dobutamine group (RR, risk ratio).

\section{RESULTS}

\section{Study selection and characteristics}

There were 22 studies including 38064 patients with decompensated heart failure in the present meta-analysis (study characteristics are listed in table 1). ${ }^{8} 11121619-36$

Fourteen trials were double blind, ${ }^{11} 161922232527-293536$ seven were open-label trials ${ }^{812} 2026313234$ and the remaining had concealed allocation. ${ }^{21} 243033$ The dose of nesiritide varied between 0 and $2 \mu \mathrm{g} / \mathrm{kg}$ (as an intravenous bolus) or between 0.005 and $0.03 \mu \mathrm{g} / \mathrm{kg} / \mathrm{min}$ (as a continuous infusion). Follow-up durations were $\leq 30$ days in 14 trials, $^{8} 121619-2123242627313637$ months in 3 trials $^{32} 3435$ and 6 months in 6 trials. $^{11} 2225283033$ A PRISMA flow diagram is shown in figure 1.

\section{Methodological quality}

We summarised the methodological quality of the Jadad score of the reported studies in table 1 . The bias assessments are shown in figure 2 according to the risk of bias.

\section{Meta-analysis}

Efficacy outcomes

The effect of nesiritide versus nitroglycerin, dobutamine or placebo on PCWP, RAP, SVR, SCr, BUN and CrCl in patients with decompensated heart failure are shown in table 2.

There were no significant differences between low-dose nesiritide and nitroglycerin in the efficacy outcomes of SCr (WMD, $-0.04 \mathrm{mg} / \mathrm{dL} ; 95 \%$ CI -0.17 to $0.08 \mathrm{mg} / \mathrm{dL} ; \mathrm{p}=0.43$ ) and $\mathrm{CrCl}(\mathrm{WMD},-0.82 \mathrm{~mL} / \mathrm{min}$; $95 \%$ CI -6.95 to $5.31 \mathrm{~mL} / \mathrm{min} ; \mathrm{p}=0.79)$. When we compared low-dose nesiritide with placebo, there were no consistent changes in SCr and BUN. Combining data from studies comparing high-dose nesiritide with placebo, results showed significant difference in SVR
(WMD, -305.17 dynes $/ \mathrm{s} / \mathrm{cm}^{5} ; \quad 95 \%$ CI -493.96 to -116.38 dynes $/ \mathrm{s} / \mathrm{cm}^{5} ; \mathrm{p}=0.002$ ).

\section{Safety outcomes}

\section{Mortality outcomes}

Forest plots of mortality outcomes are summarised in figures 3-8. Three trials contributed to the analysis on total mortality with a comparison between nesiritide and placebo (figure 3). ${ }^{16} 2123{ }^{30-35}$ Compared with placebo, nesiritide indicated no increasing risk of total mortality, with an RR of 1.04 (95\% CI 0.79 to 1.38; $p=0.76$; figure 3). As shown in figure 4 , there was no significant difference between the nesiritide and dobutamine group, regarding total mortality (RR $0.69 ; 95 \%$ CI 0.46 to $1.05 ; \mathrm{I}^{2}=0 \%$; $\mathrm{p}=0.09) .{ }^{12} 2022$ Reanalysis with a random-effects model did not change this result (RR 0.69 ; 95\% CI 0.46 to 1.02 ; $\mathrm{p}=0.89$ ). Compared with nitroglycerin, nesiritide indicated no reduction in total mortality, with an RR of 1.10 (95\% CI 0.81 to $1.49 ; \mathrm{p}=0.55$; figure 5 ). ${ }^{11}{ }^{28}{ }^{29}$ Reanalysis with a random-effects model did not change this result (RR 1.10; $95 \%$ CI 0.52 to $2.34 ; \mathrm{p}=0.24)$. Compared with the combined control therapy, nesiritide was associated with nonsignificant differences in short-term mortality (RR 1.24; $95 \%$ CI 0.85 to $1.80 ; \quad \mathrm{p}=0.27 ; \quad$ figure 6), ${ }^{12} 1620212326273031$ mid-term mortality (RR 0.86; 95\% CI 0.60 to $1.24 ; \mathrm{p}=0.42$; figure 7$)^{32} 3435$ and long-term mortality (RR 0.94; $95 \%$ CI, 0.75 to 1.18 ; $\mathrm{p}=0.61$; figure 8). ${ }^{1122} 262830$ However, no study had data regarding the safety outcome of more than 12 months.

\section{Cardiovascular adverse events}

Table 3 summarises cardiovascular adverse events identified in this meta-analysis.

In studies, nesiritide therapy increased risks of hypotension (RR $1.76 ; 95 \%$ CI 1.62 to $1.91 ; \mathrm{p}<0.00001$ ), asymptomatic hypotension (RR 1.72; 95\% CI 1.56 to 1.90; $\mathrm{p}<0.00001$ ), symptomatic hypotension (RR 1.59;

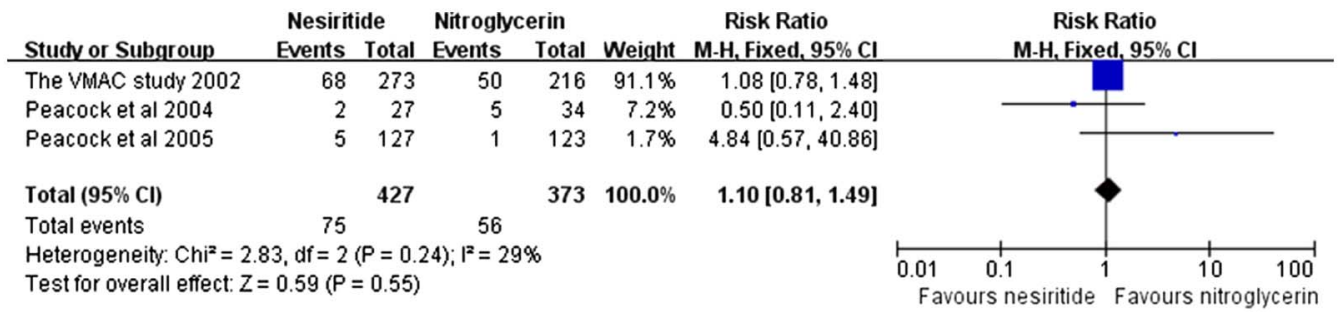

Figure 5 Meta-analysis for the comparison of total mortality in nesiritide versus nitroglycerin group. (RR, risk ratio). 


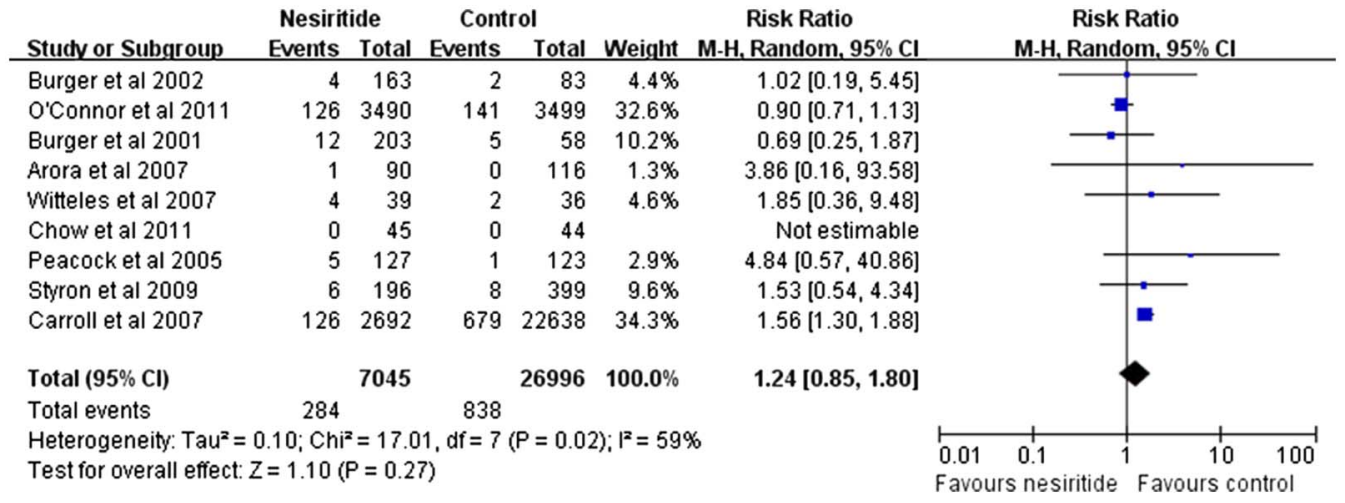

Figure 6 Funnel plots of studies assessing the comparison of short-term mortality in nesiritide therapy versus control therapy ( $R R$, risk ratio).

95\% CI 1.12 to $2.27 ; \mathrm{p}=0.01$ ) and bradycardia (RR 4.46 ; $95 \%$ CI 1.32 to $15.02, \mathrm{p}=0.02)$ in patients with heart failure compared to those using the combined control therapy. Combing data from trials comparing nesiritide therapy with the combined control therapy, the results showed significant differences in ventricular tachycardia (RR $0.43 ; 95 \%$ CI 0.30 to $0.62 ; \mathrm{p}<0.00001$ ), sustained ventricular tachycardia (RR $0.21 ; 95 \%$ CI, 0.09 to 0.49 ; $\mathrm{p}=0.0004)$, non-sustained ventricular tachycardia ( $R R$ $0.43 ; 95 \%$ CI 0.23 to $0.81 ; \mathrm{p}=0.009$ ) and cardiac arrest (RR $0.08 ; 95 \%$ CI 0.01 to $0.45 ; \mathrm{p}=0.004)$. The pooled data revealed non-statistically significant differences in ventricular extrasystole and angina pectoris.

\section{Non-cardiovascular adverse events}

Table 3 summarises non-cardiovascular adverse events identified in this meta-analysis.

Comparing nesiritide therapy with combined control therapy, the data revealed differences in the risks of headache (RR 0.37; 95\% CI 0.27 to $0.51, \mathrm{p}<0.00001$ ) and abdominal pain (RR $0.29 ; 95 \%$ CI 0.09 to 0.89 , $\mathrm{p}=0.03$ ), but not in the need for dialysis.

\section{DISCUSSION}

The objective of our meta-analysis was to assess the efficacy and safety of nesiritide, nearly 14 years after its approval for clinical use. In this meta-analysis of 22 studies involving 38064 patients, we demonstrated no significant increase in the risks of short-term, mid-term and long-term mortality. Compared with placebo, nesiritide indicated no increasing risk of total mortality. There was no significant difference between the nesiritide and dobutamine group, regarding total mortality. Compared with nitroglycerin, nesiritide indicated no reduction in total mortality. We found that, when we compared nesiritide therapy with control therapy, nesiritide therapy was associated with an increased risk of cardiovascular adverse events, such as bradycardia and hypotension (hypotension asymptomatic and hypotension symptomatic). Compared nesiritide therapy with the combined control therapy, the pooled data revealed a nonstatistically significant increase in the need for dialysis, and a significant increase in headache and abdominal pain. Importantly, in our analysis, nesiritide treatment was associated with a significant decrease in PCWP, SVR, RAP and DBP; there was no significant difference in SCr, BUN and CrCl, and none in the need for dialysis was observed.

The results of previous studies on the effect of nesiritide on survival in patients with heart failure were conflicting. Some studies showed no significant effect on mortality, ${ }^{11} 163135$ and a meta-analysis of clinical trials provided a conflicting conclusion about an increased risk of mortality. ${ }^{15}$ In what concerns short-term and long-term outcomes, a meta-analysis of seven randomised controlled trials updated in 2006 reported no significant increase in the risk of short-term and long-term mortality in nesiritide-treated patients. ${ }^{38}$ An updated meta-analysis published in 2014 provided evidence that

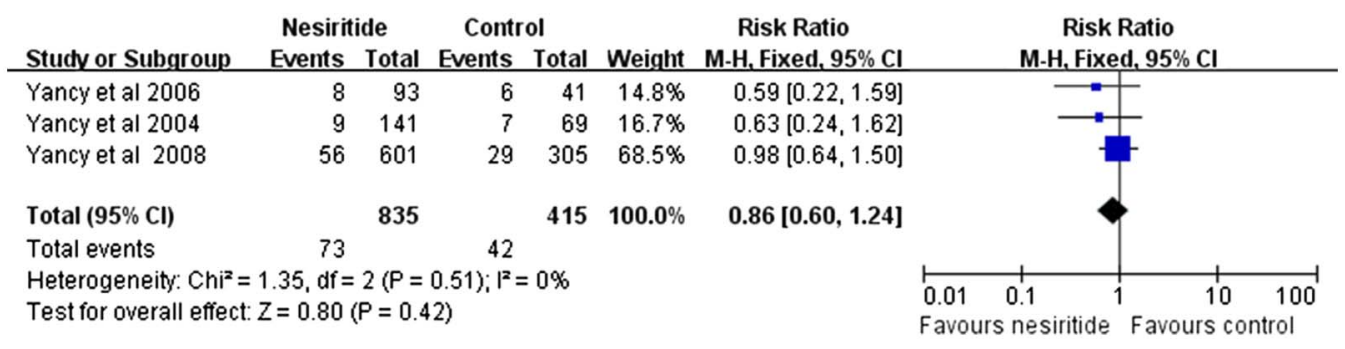

Figure 7 Funnel plots of studies assessing the comparison of mid-term mortality in nesiritide therapy versus control therapy (RR, risk ratio). 


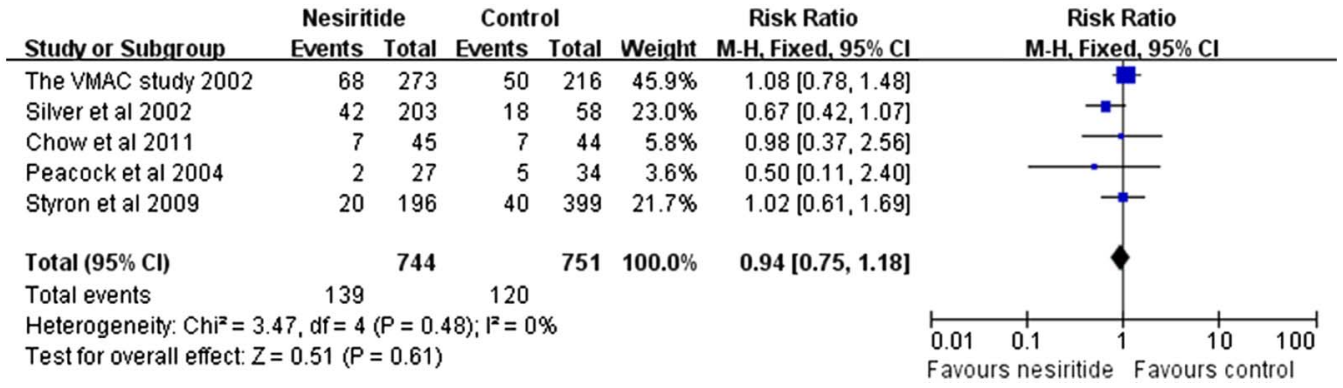

Figure 8 Funnel plots of studies assessing the comparison of long-term mortality in nesiritide therapy versus control therapy (RR, risk ratio).

nesiritide was not associated with the risk of short-term and long-term mortality. ${ }^{39}$ Our meta-analysis included a larger number of patients, and thus had increased power. Similarly, we demonstrated that nesiritide was not associated with the risk of mortality.

To the best of our knowledge, only some previous studies showed that nesiritide had effects on haemodynamic parameters such as PCWP, SVR and SBP. ${ }^{811}$ In the Nesiritide Study, ${ }^{8}$ nesiritide infusion at rates of 0.015 and $0.030 \mu \mathrm{g} / \mathrm{kg} / \mathrm{min}$ caused a dose-related increase in cardiac index and a dose-related decrease in PCWP, SVR and SBP. The study published by the Vasodilation in the Management of Acute CHF (VMAC) investigators in 2002 showed that nesiritide therapy reduced PCWP significantly more than standard therapy did, and a sustained effect was observed for at least $24 \mathrm{~h} .{ }^{11}$ In the PROACTION study, Peacock $e t a l^{29}$ demonstrated that, in the emergency department, nesiritide favourably decreased SBP of patients with elevated baseline SBP. Similarly, our meta-analysis demonstrated that nesiritide resulted in beneficial effects on haemodynamic parameters, such as decreases in SVR, SBP, DBP, PCWP and RAP. It is well known that kidney function assessment takes an essential role in patients with heart failure who have renal dysfunction. Renal insufficiency may increase risk of heart failure progression, and the pathophysiology of renal dysfunction during the process of heart failure is complex. Previous meta-analyses and studies have provided conflicting conclusions about the effect of renal function of nesiritide therapy in patients with acute decompensated heart failure. Nesiritide may be associated with a reduction in estimated glomerular filtration rate and an attenuated increase in SCr. ${ }^{1423} 3740$ A 2005 meta-analysis that focused on renal function of nesiritide found a factor of 1.5 increase in the rate of worsening renal function. ${ }^{14}$ However, a randomised controlled trial comparing nesiritide with placebo in patients with acute heart failure indicated that nesiritide was not associated with a worsening of renal function, ${ }^{16}$ and this result was in accord with some other previous studies. ${ }^{34} 4142$ In addition, according to one study, nesiritide did not induce changes in urine

\begin{tabular}{|c|c|c|c|c|c|c|}
\hline Adverse event & $\begin{array}{l}\text { Studies, } \\
\text { n }\end{array}$ & $\begin{array}{l}\text { Nesiritide group, } \\
\mathrm{n}\end{array}$ & $\begin{array}{l}\text { Control group, } \\
\mathrm{n}\end{array}$ & $\begin{array}{l}\text { Risk } \\
\text { ratio }\end{array}$ & $95 \% \mathrm{Cl}$ & $1^{2, \%}$ \\
\hline \multicolumn{7}{|l|}{ Non-cardiovascular adverse events } \\
\hline Nausea & 2 & 347 & 245 & 0.82 & 0.39 to 1.73 & 54 \\
\hline Headache & 4 & 786 & 666 & 0.37 & 0.27 to 0.51 & 19 \\
\hline Abdominal pain & 1 & 273 & 216 & 0.29 & 0.09 to 0.89 & NA \\
\hline Dialysis & 2 & 84 & 80 & 0.31 & 0.01 to 7.34 & 73 \\
\hline \multicolumn{7}{|l|}{ Cardiovascular adverse events } \\
\hline Hypotension & 16 & 6026 & 5182 & 1.76 & 1.62 to 1.91 & 65 \\
\hline Hypotension asymptomatic & 10 & 5545 & 4754 & 1.72 & 1.56 to 1.90 & 54 \\
\hline Hypotension symptomatic & 13 & 5778 & 4915 & 1.59 & 1.12 to 2.27 & 48 \\
\hline Ventricular extrasystole & 2 & 451 & 227 & 0.51 & 0.25 to 1.01 & 0 \\
\hline Ventricular tachycardia & 5 & 977 & 460 & 0.43 & 0.30 to 0.62 & 32 \\
\hline Sustained ventricular tachycardia & 4 & 857 & 343 & 0.21 & 0.09 to 0.49 & 25 \\
\hline $\begin{array}{l}\text { Non-sustained ventricular } \\
\text { tachycardia }\end{array}$ & 5 & 977 & 460 & 0.43 & 0.23 to 0.81 & 56 \\
\hline Cardiac arrest & 3 & 694 & 260 & 0.08 & 0.01 to 0.45 & 0 \\
\hline Bradycardia & 4 & 927 & 501 & 4.46 & 1.32 to 15.02 & 0 \\
\hline Angina pectoris & 1 & 273 & 216 & 0.79 & 0.23 to 2.70 & NA \\
\hline
\end{tabular}


output, effective renal plasma flow and glomerular filtration rate. ${ }^{11}$ A current meta-analysis also found that nesiritide may have a dose-dependent effect on renal function in patients with acute decompensated heart failure. In the high-dose nesiritide group, nesiritide treatment was strongly associated with renal function $(\mathrm{p}=0.001)$. However, in standard-dose and low-dose groups, no statistical differences were observed. ${ }^{43}$

Our meta-analysis is in agreement with previous studies showing that nesiritide has no significant effects on $\mathrm{SCr}, \mathrm{BUN}$ and $\mathrm{CrCl}$, and has no risk of the need for dialysis.

Nesiritide not only has a greater incidence of cardiovascular adverse events, but also has a higher risk of non-cardiovascular adverse events. It provides rapid effects by itself and has a distribution half-life of approximately $2 \mathrm{~min}$, a mean terminal elimination halflife of approximately $18 \mathrm{~min}$ and multiple routes of elimination. The half-life of $18 \mathrm{~min}$ of nesiritide is associated with favourable adverse events in patients with heart failure. Earlier reports have described cardiovascular adverse events, including hypotension, ventricular tachycardia, cardiac arrest, bradycardia, atrial fibrillation and ventricular extrasystole. It is noteworthy that nesiritide causes a dose-dependent increase in hypotension as the most common adverse effect, usually with asymptomatic or mild symptoms. ${ }^{8} 16$ The effects of nesiritide on bradycardia and hypotensive may be associated with the autonomic nervous system. This effect is mediated by both central inhibition of sympathetic neurotransmission and inhibition of sympathetic-mediated reduction. ${ }^{44}$ One study documented that the incidence of sustained ventricular tachycardia and cardiac arrest increased by approximately 12-fold, and the risk of nonsustained ventricular tachycardia increased by 1.5 -fold, in the dobutamine group compared with nesiritide group. ${ }^{20}$ Our meta-analysis demonstrated no significant adverse events such as nausea and the need for dialysis, however, it did show adverse events for the infusion of nesiritide in patients with heart failure. However, levosimendan therapy showed higher risks of hypotension, ventricular tachycardia, cardiac arrest, bradycardia, headache and abdominal pain than control therapy did.

\section{CONCLUSIONS}

In conclusion, this meta-analysis confirmed that nesiritide therapy was not found to have significant impacts on $\mathrm{SCr}, \mathrm{BUN}$ and $\mathrm{CrCl}$, and no risk of the need for dialysis was observed. In contrast, nesiritide treatment was associated with significant positive effects on haemodynamic parameters. In view of the wide choice of heart failure treatment, nesiritide was not associated with the risk of mortality. Significant differences in adverse events for infusion of nesiritide in hypotension and bradycardia were observed. However, no significant difference on the need for dialysis was found.
Contributors BG is the guarantor. BG drafted the manuscript. All the authors contributed to the development of the selection criteria, the risk of bias assessment strategy and data extraction criteria, the search strategy and statistical expertise. All the authors read, provided feedback and approved the final manuscript. BG and ZL conceived and designed the experiments. BG, $Z W$ and $Z L$ performed the experiments. $B G$ and $Z W$ analysed the data. $B G$ and $\mathrm{ZL}$ contributed reagents/materials/analysis tools. $\mathrm{BG}$ and $\mathrm{ZW}$ wrote the paper.

Funding This research was supported by the Ministry of Science and Technology of Guangzhou (grant number 2014Y2-00128)

Competing interests None declared.

Patient consent Obtained.

Ethics approval Committee on Publication Ethics.

Provenance and peer review Not commissioned; externally peer reviewed.

Data sharing statement No additional data are available.

Open Access This is an Open Access article distributed in accordance with the Creative Commons Attribution Non Commercial (CC BY-NC 4.0) license, which permits others to distribute, remix, adapt, build upon this work noncommercially, and license their derivative works on different terms, provided the original work is properly cited and the use is non-commercial. See: http:// creativecommons.org/licenses/by-nc/4.0/

\section{REFERENCES}

1. Sharpe N, Doughty R. Epidemiology of heart failure and ventricular dysfunction. Lancet 1998;352:S13-17.

2. Roger VL, Go AS, Lloyd-Jones DM, et al. Heart disease and stroke statistics-2012 update: a report from the American Heart Association. Circulation 2012;125:e2-220.

3. Kubo SH, Rector TS, Bank AJ, et al. Endothelium-dependent vasodilation is attenuated in patients with heart failure. Circulation 1991;84:1589-96.

4. Varin $\mathrm{R}$, Mulder $\mathrm{P}$, Tamion $\mathrm{F}$, et al. Improvement of endothelial function by chronic angiotensin-converting enzyme inhibition in heart failure: role of nitric oxide, prostanoids, oxidant stress, and bradykinin. Circulation 2000;102:351-6.

5. Keith M, Geranmayegan A, Sole MJ, et al. Increased oxidative stress in patients with congestive heart failure. J Am Coll Cardiol 1998;31:1352-6.

6. Reichlin T, Socrates T, Egli $\mathrm{P}$, et al. Use of myeloperoxidase for risk stratification in acute heart failure. Clin Chem 2010;56:944-51.

7. Clarkson PB, Wheeldon NM, Macleod C, et al. Brain natriuretic peptide: effect on left ventricular filling patterns in healthy subjects. Clin Sci (Lond) 1995;88:159-64.

8. Colucci WS, Elkayam U, Horton DP, et al. Intravenous nesiritide, a natriuretic peptide, in the treatment of decompensated congestive heart failure. N Engl J Med 2000;343:246-53.

9. Zellner C, Protter AA, Ko E, et al. Coronary vasodilator effects of BNP: mechanisms of action in coronary conductance and resistance arteries. Am J Physiol 1999;276:H1049-57.

10. Hosoda K, Nakao K, Mukoyama M, et al. Expression of brain natriuretic peptide gene in human heart. Production in the ventricle. Hypertension 1991;17:1152-5

11. Publication committee for the VMAC investigators (vasodilatation in the management of acute CHF). Intravenous nesiritide vs nitroglycerin for treatment of decompensated congestive heart failure: a randomized controlled trial. JAMA 2002;287:1531-40.

12. Burger AJ, Horton DP, LeJemtel T, et al. Effect of nesiritide (B-type natriuretic peptide) and dobutamine on ventricular arrhythmias in the treatment of patients with acutely decompensated congestive heart failure: the PRECEDENT study. Am Heart J 2002;144:1102-8.

13. Michaels AD, Klein A, Madden JA, et al. Effects of intravenous nesiritide on human coronary vasomotor regulation and myocardial oxygen uptake. Circulation 2003;107:2697-701.

14. Sackner-Bernstein JD, Skopicki HA, Aaronson KD. Risk of worsening renal function with nesiritide in patients with acutely decompensated heart failure. Circulation 2005;111:1487-91.

15. Sackner-Bernstein JD, Kowalski M, Fox M, et al. Short-term risk of death after treatment with nesiritide for decompensated heart failure: a pooled analysis of randomized controlled trials. JAMA 2005;293:1900-5.

16. O'Connor CM, Starling RC, Hernandez AF, et al. Effect of nesiritide in patients with acute decompensated heart failure. $N$ Engl J Med 2011;365:32-43. 
17. Thacker S. Meta-analysis. A quantitative approach to research integration. JAMA 1988;259:1685-9.

18. Mantel N, Haenszel W. Statistical aspects of the analysis of data from retrospective studies of disease. J Natl Cancer Inst 1959;22:719-48.

19. Abraham WT, Cheng ML, Smoluk G, et al. Clinical and hemodynamic effects of nesiritide (B-type natriuretic peptide) in patients with decompensated heart failure receiving beta blockers. Congest Heart Fail 2005;11:59-64.

20. Burger AJ, Elkayam U, Neibaur MT, et al. Comparison of the occurrence of ventricular arrhythmias in patients with acutely decompensated congestive heart failure receiving dobutamine versus nesiritide therapy. Am J Cardiol 2001;88:35-9.

21. Arora S, Clarke K, Srinivasan V, et al. Effect of nesiritide on renal function in patients admitted for decompensated heart failure. QJM 2007;100:699-706.

22. Silver MA, Horton DP, Ghali JK, et al. Effect of nesiritide versus dobutamine on short-term outcomes in the treatment of patients with acutely decompensated heart failure. J Am Coll Cardiol 2002;39:798-803.

23. Witteles RM, Kao D, Christopherson D, et al. Impact of nesiritide on renal function in patients with acute decompensated heart failure and pre-existing renal dysfunction a randomized, double-blind, placebo-controlled clinical trial. J Am Coll Cardiol 2007;50:1835-40.

24. Aronson D, Burger AJ. Intravenous nesiritide (human B-type natriuretic peptide) reduces plasma endothelin-1 levels in patients with decompensated congestive heart failure. Am J Cardiol 2002;90:435-8.

25. Chen $\mathrm{HH}$, Anstrom KJ, Givertz MM, et al. Low-dose dopamine or low-dose nesiritide in acute heart failure with renal dysfunction: the ROSE acute heart failure randomized trial. JAMA 2013;310:2533-43.

26. Chow SL, O'Barr SA, Peng J, et al. Modulation of novel cardiorenal and inflammatory biomarkers by intravenous nitroglycerin and nesiritide in acute decompensated heart failure: an exploratory study. Circ Heart Fail 2011;4:450-5.

27. Peacock WF, Emerman CL, Silver MA. Nesiritide added to standard care favorably reduces systolic blood pressure compared with standard care alone in patients with acute decompensated heart failure. Am J Emerg Med 2005;23:327-31.

28. Peacock WF IV, Emerman CL, Young J. Nesiritide in congestive heart failure associated with acute coronary syndromes: a pilot study of safety and efficacy. J Card Fail 2004;10:120-5.

29. Peacock WF IV, Holland R, Gyarmathy $R$, et al. Observation unit treatment of heart failure with nesiritide: results from the proaction trial. J Emerg Med 2005;29:243-52.

30. Styron JF, Jois-Bilowich P, Tallman T, et al. Outcomes associated with nesiritide administration for acute decompensated heart failure in the emergency department observation unit: a single center experience. Congest Heart Fail 2009;15:103-7.
31. Carroll RJ, Mulla ZD, Hauck LD, et al. Outcomes of patients hospitalized for acute decompensated heart failure: does nesiritide make a difference? BMC Cardiovasc Disord 2007;7:37.

32. Yancy CW, Singh A. Potential applications of outpatient nesiritide infusions in patients with advanced heart failure and concomitant renal insufficiency (from the Follow-Up Serial Infusions of Nesiritide [FUSION I] trial). Am J Cardiol 2006;98:226-9.

33. Chow SL, O'Barr SA, Peng J, et al. Renal function and neurohormonal changes following intravenous infusions of nitroglycerin versus nesiritide in patients with acute decompensated heart failure. J Card Fail 2011;17:181-7.

34. Yancy CW, Saltzberg MT, Berkowitz RL, et al. Safety and feasibility of using serial infusions of nesiritide for heart failure in an outpatient setting (from the FUSION I trial). Am J Cardiol 2004;94:595-601.

35. Yancy CW, Krum H, Massie BM, et al. Safety and efficacy of outpatient nesiritide in patients with advanced heart failure: results of the Second Follow-Up Serial Infusions of Nesiritide (FUSION II) trial. Circ Heart Fail 2008;1:9-16.

36. Mills RM, LeJemtel TH, Horton DP, et al. Sustained hemodynamic effects of an infusion of nesiritide (human b-type natriuretic peptide) in heart failure. J Am Coll Cardiol 1999;34:155-62.

37. Mentzer RM Jr, Oz MC, Sladen RN, et al. Effects of perioperative nesiritide in patients with left ventricular dysfunction undergoing cardiac surgery-the NAPA trial. Am J Cardiol 2007;49:716-26.

38. Arora RR, Venkatesh PK, Molnar J. Short and long-term mortality with nesiritide. Am Heart J 2006;152:1084-90.

39. Xiong B, Wang C, Yao Y, et al The dose-dependent effect of nesiritide on renal function in patients with acute decompensated heart failure: a systematic review and meta-analysis of randomized controlled trials. PLOS ONE 2015;10:e0131326.

40. Chow SL, Peng JT, Okamoto MP, et al. Effect of nesiritide infusion duration on renal function in acutely decompensated heart failure patients. J Clin Endocrinol Metab 2007:41:556-61.

41. Iglesias $\mathrm{J}$, Hom D, Antoniotti $\mathrm{M}$, et al. Predictors of worsening renal function in adult patients with congestive heart failure receiving recombinant human B-type brain natriuretic peptide (nesiritide) Nephrol Dial Transplant 2006;21:3458-65.

42. Yancy CW, Krum H, Massie BM, et al. The second follow-up serial infusions of nesiritide (FUSION II) trial for advanced heart failure: study rationale and design. Am Heart $J$ 2007;153:478-84.

43. Yan B, Peng L, Zhao $X$, et al. Nesiritide fails to reduce the mortality of patients with acute decompensated heart failure: an updated systematic review and cumulative meta-analysis. Int $\mathrm{J}$ Cardiol 2014;177:505-9.

44. Floras JS. Sympathoinhibitory effects of atrial natriuretic factor in normal humans. Circulation 1990;81:1860-73.

45. Atchison DJ, Ackermann U. The interaction between atrial natriuretic peptide and cardiac parasympathetic function. $J$ Auton Nerv Syst 1993;42:81-8. 